\title{
NIKAH SIRI DAN IMPLIKASINYA TERHADAP KEHIDUPAN SOSIAL ANAK DI ACEH TAMIANG (Studi Sosiologi Hukum Islam)
}

\author{
Samsul Bahri \\ Agraria dan Tata Ruang/ Badan Pertanahan Nasional Kota Langsa \\ Email solebahri@gmail.com
}

\begin{abstract}
In Aceh Tamiang, there are still many unmarried couples such as in Paya Bedi Village, Kejuruan Muda District. The practice of siri marriage in Aceh Tamiang District has been going on for a long time in Lhok Medang Ara and Sampaimah Villages, Manyak Payed District and is considered a normal thing by the community even though it is done covertly and is difficult to detect. Social implications for children's life in the family environment such as the loss of civil relations with their fathers. Social implications for children's lives in the community are considered to be underestimated as illegitimate children and often become tools of exploitation, as well as social implications for the life of children after the death of parents, namely children cannot claim inheritance rights from their father
\end{abstract}

\begin{abstract}
Abstrak
Di Aceh Tamiang masih banyak ditemukan pasangan nikah siri seperti di Desa Paya Bedi Kecamatan Kejuruan Muda. Praktik nikah siri di Kabupaten Aceh Tamiang sudah berlangsung sejak lama di Desa Lhok Medang Ara dan Desa Sampaimah Kecamatan Manyak Payed dan dianggap hal yang biasa oleh masyarakat meskipun dilakukan secara terselubung dan sulit dideteksi. Implikasi sosial terhadap kehidupan anak dalam lingkungan keluarga seperti hilangnya hubungan perdata dengan ayahnya. Implikasi sosial terhadap kehidupan anak dalam lingkungan masyarakat yaitu dianggap rendah sebagai anak haram dan sering menjadi alat ekploitasi, serta implikasi sosial terhadap kehidupan anak pasca meninggal orang tua yaitu anak tidak dapat menuntut hak warisan dari ayahnya.
\end{abstract}

Kata Kunci : Nikah Siri, Kehidupan Sosial Anak, Sosiologi Hukum Islam 


\section{Pendahuluan}

Perkawinan merupakan hubungan lahir batin antara seorang lakilaki dengan seorang perempuan yang telah cukup persyaratan untuk melakukan pernikahan dengan tujuan untuk membangun rumah tangga yang kekal, bahagia serta menuju ke dalam hubungan yang baik antara sesama manusia dan menjadi hubungan ibadah kepada Allah SWT. Sebagaimana yang disebut pada Pasal 1 Undang-Undang Nomor 1 Tahun 1974 tentang Perkawinan yang menyatakan bahwa perkawinan adalah ikatan lahir batin antara seorang pria dengan seorang wanita sebagai suami istri dengan tujuan membentuk keluarga (rumah tangga) yang bahagia dan kekal berdasarkan Ketuhanan Yang Maha Esa, (UU Nomor 1 Tahun 1974).

Hukum Islam mengatur perkawinan atau pernikahan sebagai cara menghormati dan menghargai harga diri yang diberikan oleh Islam untuk manusia dengan makhluk lainnya, (al-Shabbaqh 2004: 23). Pergaulan lakilaki dan wanita menjadi terhormat dari adanya suatu pernikahan yang sah walaupun sesuai dengan peradaban manusia serta dapat membangun keluarga yang damai, penuh kasih sayang antara pasangan suami istri.

Dalam kajian hukum Islam dan hukum positif perkawinan dapat ditinjau dari segi hukum, segi sosial dan juga segi ibadah, (Mukhtar 2009: 45). Dari segi hukum perkawinan dianggap suatu perjanjian yang kuat dan kokoh. Dari segi sosial perkawinan dianggap dapat mengangkat harkat martabat wanita hingga tidak dibenarkan bersikap sewenang-wenang karena dalam perkawinan itu lahir anak-anak yang sah. Sedangkan dari segi ibadah perkawinan diangap suatu peristiwa penting dan sakral serta mengandung nilai-nilai ibadah. Bahkan dengan tegas Nabi Muhammad SAW menyebutkan perkawinan punya nilai yang sama dengan separuh nilai keberagamaan. Pasal 2 Undang-Undang Nomor 1 Tahun 1974 tentang Perkawinan menyebutkan bahwa: Perkawinan adalah sah apabila dilakukan menurut hukum masing-masing agama dan kepercayaannya, dan Tiap-tiap perkawinan dicatat menurut peraturan perundang-undangan yang berlaku, (Khairuddin 2005: 27).

Dengan demikian suatu perkawinan dianggap sah apabila dilaksanakan sesuai hukum agama/kepercayaan masing-masing para pihak. Hal tersebut berarti jika suatu perkawinan telah mencukupi syarat dan rukun nikah serta dilakukan ijab kabul maka perkawinan tersebut sah menurut agama dan kepercayaan masyarakat.

Pencatatan perkawinan adalah hal yang sangat penting, karena jika tidak dicatat akan berakibat tidak baik pada pasangan perkawinan siri dan keturunannya. Salah satu dampak negatif pasangan nikah siri yang paling banyak dialami oleh pihak wanita sebagai pasangan dari kawin siri serta anak yang lahir darinya. 
Negara menegaskan mengenai kewajiban pencatatan perkawinan dalam peraturan perundang-undangan untuk tujuan kemaslahatan warga negaranya. Karena dengan perkawinan siri bagi laki-laki yang tidak bertanggungjawab, akan dengan mudah tidak melakukan apa yang menjadi kewajibannya terhadap istri dan anak-anaknya, dengan mudah melakukan kawin-cerai seenak hatinya.

Sahnya perkawinan ini di mata agama dan kepercayaan masyarakat perlu disahkan lagi oleh negara, yang dalam hal ini ketentuannya terdapat pada Pasal 2 Ayat (2) Undang-Undang Nomor 1 Tahun 1974 tentang Perkawinan. Pencatatan setiap perkawinan sama halnya dengan pencatatan suatu peristiwa hukum kedalam suatu akta resmi (surat keterangan) yang dimuat dalam daftar pencatatan yang disediakann khusus untuk itu (Sayuti 2009: 75).

Dampak hukum lain dari perkawinan siri yaitu dirasakan oleh anak yang dilahirkan. Anak tidak mempunyai hubungan perdata dengan bapak biologisnya dan hanya pada ibu dan keluarga ibunya, sebagaimana tercantum dalam Pasal 43 ayat (1) Undang-Undang Nomor 1 Tahun 1974 tentang Perkawinan menyebutkan bahwa "Anak yang dilahirkan diluar perkawinan hanya mempunyai hubungan perdata dengan ibunya dan keluarga ibunya".

Nikah siri oleh negara belum dianggap sah dan anak yang lahir disebutkan sebagai anak yang dilahirkan diluar perkawinan, hal ini berbeda pandangan kalau dilihat dari sudut pandang agama. Terkait dengan Pasal 2 ayat (2) dan Pasal 43 ayat (1) Undang-Undang Perkawinan yang telah diajukan permohonan pengujian terhadap Undang-Undang Dasar Negara Republik Indonesia Tahun 1945 yang diajukan oleh $\mathrm{Hj}$. Aisyah Mochtar alias Machica binti H. Mochtar Ibrahim dan Muhammad Iqbal Ramadhan, Mahkamah Konstitusi telah mengabulkan sebagian permohonan pengujian tersebut, dengan putusan Nomor 46/PUUVIII/2010.

Hukum perkawinan merupakan salah satu aspek yang paling banyak diterapkan oleh kaum muslimin di seluruh dunia dibanding dengan hukum-hukumm muamalah yang lain, (Anderson 1994: 46). Menurut Al-qur'an dan hadis, para ulama menyimpulkan bahwa ha-hal yang termasuk rukun pernikahan adalah calon suami, calon istri, wali nikah, dua orang saksi, ijab dan qabul. Kewajiban akan adanya saksi ini adalah pendapat Syafi'i, Hanafi dan Hanbali sebagaimana yag dikutiip oleh Mahmud Yunus, (Mahmud 1996: 18).

Syarat sah nikah menurut Wahbah Zuhaili yaitu antara suami istri tidak ada hubungan nasab, kutipan ijab qabul tidak dibatasi waktu, adanya persaksian, tidak ada paksaan, ada kejelasan calon suami istri, tidak sedang ihram, ada mahar, tidak ada kesepakatan untuk 
menyembunyikan akad nikah salah satu calon mempelai tidak sedang menderita penyakit kronis, dan adanya wali, (az-Zuhaili 2011: 91).

Selanjutnya menurut Imam Abu Hanifah sebagaimana yang dikutip Muhammad Jawad Mughniyah menyebutkan yang dimaksud dengan nikah siri adalah nikah yang tidak bisa menghadirkan wali dan tidak mendaftarkannya pada lembaga perkawinan. Beliau menetapkan bahwa wanita yang telah balig dan berakal (dalam kondisi normal) maka diperbolehkan memilih sendiri calon suaminya dan dirinya tidak hanya tergantung pada walinya saja. Nikah siri dilakukan biasanya karena alasan dua pihak belum siap meresmikannya atau meramaikannya. Namun di sisi lain nikah siri dilakukan dengan tujuan untuk menjaga agar tidak terjerumus kepada perbuatan zina, (Mughniyah 2008: 348).

Istilah nikah siri memang sudah dikenal di kalangan para ulama. Dulu nikah siri yang dimaksud merupakan pernikahan sesuai dengan rukun dan syarat perkawinan menurut hukum islam, akan tetapi saksi diminta tidak memberitahukan terjadinya pelaksanaan nikah siri tersebut kepada orang ramai, masyarakat, dan tidak ada acara peresmian, (Devita, Akibat Hukum Dari Nikah Siri, http:/ / irmadevita.com).

Namun sekarang nikah siri yang dikenal oleh masyarakat yaitu perkawinan yang dilakukan sesuai ruku dan syarat agama tetapi tidak dilakukan dihadapan Petugas Pencatat Nikah atau tidak dicatatkan di Kantor Urusan Agama bagi yang beragama Islam atau di Kantor Catatan Sipil bagi yang tidak beragama Islam.

Untuk itu, perlu ditegaskan bahwa nikah siri yang dimaksudkan dalam penelitian ini yaitu pelaksanaan perkawinan yang tidak dicatatkan sebagaimana yang ditentukan oleh Undang-Undang Nomor 1 Tahun 1974 tentang Perkawinan oleh Negara melalui lembaga berwenang seperti Kantor Urusan Agama (KUA). Meski perkawinan tersebut dilaksanakan sah menurut agama karena memenuhi syarat perkawinan namun tidak memiliki kepastian hukum untuk melindungi hak-hak yang timbull dari suatu perkawinan.

Nikah siri yang tidak dicatatkan menurut perundang-undangan yang berlaku, secara hukum perkawinan tersebut dianggap tidak pernah ada. Seperti yang terjadi di Aceh Tamiang tepatnya di Desa Paya Bedi Kecamatan Kejuruan Muda Kabupaten Aceh Tamiang, sepasang suami istri berinisial Sukirno (46) bersama Siti Sundari (43) melangsungkan pernikahan dengan cara kawin siri atau perkawinan di bawah tangan;

Rumah tangga mereka sudah berlangsung selama tiga tahun dan memiliki dua anak. Dalam kehidupan rumah tangganya mereka hidup harmonis dan tidak memiliki permasalahan yang signifikan. Namun secara hukum setiap perkawinan memiliki implikasi terhadap kehidupan sosial serta perlindungan hukum terhadap hakhak istri dan anak tidak dapat dipenuhi. Misalnya dalam 
pengurusan akta kelahiran pada saat anaknya masuk sekolah, (Sukirno, Paya Bedi, Wawancara pada tanggal 20 Maret 2019), (Sukirno, Paya Bedi, Wawancara pada tanggal 20 Maret 2019).

Selain itu, pasangan Hidayat (45) dengan Hayatun Nufus (41) di Desa Terban Kecamatan Karang Baru Kabupaten Aceh Tamiang. Hayatun Nufus merupakan istri kedua dari Hidayat pernikahan mereka dilangsungkan secara siri atau perkawinan di bawah tangan; "Perkawinan mereka sudah berlangsung selama tiga tahun dan sering terjadi pertengkaran. Namun dikarenakan perkawinan siri maka istri tidak dapat menggugat hak-hak anaknya untuk dilindungi oleh negara", (Hayatun Nufus, Wawancara pada tanggal 20 Maret 2019).

Berdasarkan permasalahan di atas penulis tertarik untuk menjadikannya sebuah karya ilmiah dalam bentuk jurnal dengan judul "Nikah Siri dan Implikasinya Terhadap Kehidupan Sosial Anak di Aceh Tamiang (Studi Sosiologi Hukum Islam)".

\section{Deskripi Umum Praktik Nikah Siri di Aceh Tamiang}

Nikah siri diartikan sebagai bentuk pernikahan yang dilakukan hanya berdasarkan aturan agama atau adat istiadat. Nikah siri tidak diumumkan kepada khalayak umum dan tidak tercatat resmi di Kantor Urusan Agama atau Kantor Catatan Sipil untuk mendapatkan suatu kepastian hukum. Menurut A. Latif Rusydi Azhari Harahap, nikah siri adalah suatu pernikahan yang tidak memenuhi syarat administrasi yang telah diatur oleh Negara, karena nikah siri merupakan pernikahan yang tidak dicatatkan di Kantor Urusan Agama;

Oleh karena itu, nikah siri menimbulkan dampak negatif yang merugikan pasangan yang melakukannya terutama bagi perempuan dan anak. Salah satu dampak negatif dari nikah siri secara hukum kenegaraan adalah tidak diakuinya hak-hak keperdataan yang ditimbulkan oleh hubungan pernikahan siri, tidak dianggap istri sah dan tidak berhak atas nafkah dan warisan dari suami jika nantinya meninggal dunia, (A. Latif Rusydi Azhari Harahap, Wawancara pada tanggal 26 Maret 2019).

Praktik nikah siri di kabupaten Aceh Tamiang sudah berlangsung sejak lama dikarenakan masih ada di beberapa tempat layanan jasa praktik nikah siri ini masih dilakukan. Seperti praktik nikah siri yang dilakukan di Desa Medang Ara Kecamatan Karang Baru dan Desa Sampaimah Kecamatan Manyak Payed, layanan praktik nikah siri ini masih saja tersedia dan pasangan yang hendak nikah siri dapat mewujudkannya disana. Menurut Rusham praktik nikah siri di Desa Medang Ara Kecamatan Karang Baru; 
Dari tahun ke tahun pasangan yang nikah siri semakin berkurang jumlahnya. Akan tetapi, masih saja ada beberapa pasangan yang ingin melakukannya nikah siri dan hampir setiap tahun kebanyakan pasangan duda dan janda yang melaksanakan nikah siri tersebut. Hal itu dikarenakan berbagai sebab seperti lamanya menunggu akta cerai dari Mahkamah Syar'iyah, sehingga memilih jalur menikah secara siri, (Rusham, Lhok Medang Ara, Wawancara pada tanggal 30 April 2019).

Pelaksanaan praktik nikah siri dilakukan oleh qadhi untuk membantu pasangan yang kesulitan melakukan nikah biasa karena tidak mendapatkan restu dari orang tua;

Maka praktek nikah siri ini masih juga dilakukan oleh qadhi dianggap masih dibutuhkan jasa praktik nikah siri maka bagi qadhi praktik nikah siri masih menjadi kegiatan sebagai media untuk mencari sumber pendapatan bagi qadhi itu sendiri, karena dalam sekali melangsungkan praktik nikah siri bagi qadhi mendapatkan bayaran antara seratus ribu hingga lima ratus ribu per pasangan, jadi kalau dilihat dari segi pendapatan jumlah tersebut juga sangat tergantung kepada kebutuhan dari pasangan yang melakukan pernikahan. Misalnya saksi harus disediakan oleh qadhi maka bayarannya dipatokkan lebih tinggi, (Ansyari, Sampaimah, Wawancara pada tanggal 3 Mei 2019).

Bagi masyarakat sekitar tempat praktik nikah siri itu dianggap hal yang biasa oleh masyarakat sekitar karena hal itu sudah berlangsung sejak lama. Menurut Rahmad, praktik nikah siri di Desa Medang Ara Kecamatan Karang Baru sudah ada sejak tahun 1998. "Bahkan Desa Medang Ara Kecamatan Karang Baru sudah dicap sebagai Desa nikah siri oleh masyarakat sekitar, karena setiap pasangan yang hendak melangsungkan nikah siri akan berkunjung ke Desa tersebut", (Rahmad, Lhok Medang Ara, Wawancara pada tanggal 30 April 2019).

Menurut Khairul Abadi, selaku Datok Penghulu Desa Medang Ara, menyarankan kepada warganya untuk menghindari praktik nikah siri dikarenakan itu akan merugikan bagi pasangan baik suami, istri maupun anak;

Meskipun begitu, Datok Penghulu tidak dapat melarang warganya yang menyelenggarakan praktik nikah siri dikarenakan itu wewenang aparat penegak hukum, peserta nikah siripun kebanyakan warga yang berasal dari daerah lain yang datang ke Desa tersebut. Menurut Ansyaruddin, praktik nikah siri tersebut sulit dihilangkan selama orang yang berkeinginan nikah siri masih ada. Selain itu, praktik nikah siri dilakukan secara terselubungg dan 
sulit dideteksi praktiknya, (Ansyaruddin, Wawancara pada tanggal 26 Maret 2019).

Praktik nikah siri di Aceh Tamiang dilatar belakangi oleh alasan yang berbeda bagi setiap pasangan, namun secara umum adalah sama yaitu ingin memperoleh keabsahan. Dalam hal ini yang dipahami oleh masyarakat adalah pernikahan siri sudah sah secara agama. Sebagian masyarakat masih banyak yang berpendapat nikah merupakan urusan pribadi dalam melaksanakan ajaran agama, jadi tidak perlu melibatkan aparat yang berwenang dalam hal ini Kantor Urusan Agama (KUA). Disamping itu nika siri juga dianggap sebagai jalan pintas bagi pasangan yang menginginkan pernikahan namun belum siap atau ada hal-hal lain yang tidak memungkinkan-nya terikat secara hukum.

Nikah siri merupakan perjanjian antara laki-laki dan perempuan untuk bersuami istri yang dilakukan secara diam-diam atau tertutup. Hakikat nikah siri tersebut pada dasarnya merupakan perkawinan yang dilakukan tanpa dicatatkan, jadi istilah nikah siri adalah istilah yang berkembang di Indonesia saja yang bermakna pernikahan tanpa tercatat di Kantor Urusan Agama.

Nikah siri sebenarnya juga merupakan nikah yang sakral dan sah secara agama apabila dilakukan sesuai dengan syariat dan niat yang benar. Memang ada yang berniat serius nikah siri dengan tujuan membangun keluarga yang sakinah, mawadah, dan wa rahmah. Namun sampai sekarang nikah siri sering dijadikan alasan bagi orang-orang yang ingin melegalkan seksualitas. Nika siri dianggap dapat menghindari zina padahal justru pihak perempuan menjadi korban. Apabila suami ingin bercerai tinggal melakukan talak, dan istri tidak dapat menuntut apapun karena tidak ada kepastian hukum yang berlaku di Mahkamah Syar'iyah. Bagi pasangan yang suka kawin cerai, nikah siri tentunya sangat diminati karena pada dasarnya syarat yang harus dipenuhi sebuah pernikahan itu mudah. Yang sulit dari suatu pernikahan yaitu tanggung jawab untuk membina rumah tangga itu sendiri. Menurut Rusham, praktik pelaksanaan nikah siri dilakukan sesuai dengan rukun nikah yang ditetapkan dalam hukum Islam;

Menurut Islam maksudnya adanya kedua mempelai, wali nikah, dua orang saksi serta ijab kabul. Namun terlepas dari itu, yang unsur yang paling penting dalam pelaksanaan nikah siri itu adalah niat dari pasangan tersebut dan tujuannya harus disertai tekad yang kuat bukan hanya semata untuk menghindari perzinahan tetapi untuk membangun rumah tangga yang kekal, (Rusham, Lhok Medang Ara, Wawancara pada tanggal 30 April 2019).

Nilai yang dominan yaitu berkaitan dengan nilai yang ada dalam agama islam, yang sesuai dengan tingkat pemahaman dan 
keterpengaruhan pelakunya. Alasannya karena nikah siri mengacu pada nilai atau ajaran yang terdapat dalam agama islam. Orientasi nilai yang terkandung dari merahasiakan pernikahan tersebut, karena disebabkan adanya anggapan. Di antara anggapan tersebut adalah: pertama, bahwa prosesi ijab qabul atau pernikahan yang dipimpin oleh ulama lebih utama (afdhal) jika dibanding dengan petugas pemerintah dalam hal ini KUA. Dalam hal ini kualitas dan intregritas spiritual kadang kala menjadi pertimbangan yang sangat penting. Kedua, bahwa nikah siri biasanya dilakukan oleh orang-orang yang sama atau satu komunitas. Dalam hal ini berarti orang-orang yang masih dalam satu agama, sebab adanya satu pemahaman dan memiliki intregritas agama yang bagus, (Nurhaedi 2013: 187-190).

Hal yang paling penting dalam pelaksanaan nikah adalah terpenuhinya rukun sesuai agama islam. Namun pentingnya pencatatan nikah juga ditujukan untuk memberikan perlindungan hukum terutama bagi istri dan anak jika kemudian hari terjadi konflik rumah tangga dan biasanya istri dan anak menjadi korban. Untuk itu pencatatan nikah diperlukan agar Negara bisa ikut campur dalam upaya penyelesaian dampak dari perselisihan rumah tangga yang dilakukan oleh pasangan yang berumah tangga.

\section{Implikasi Sosial Terhadap Kehidupan Anak dalam Lingkungan Keluarga}

Nikah siri merupakan nikah yang dilaksanakan secara sembunyisembunyi tanpa adanya pencatatan oleh KUA Kecamatan atau Kabupaten selaku Instansi berwenang, yang membidangi masalah pernikahan, hal ini dilakukan oleh pasangan yang melaksanakan nikah siri sebagai upaya untuk menyembunyikan dari masyarakat luas. Menurut Hasan Basri; "nikah siri dianggap tidak sah menurut hukum Negara dan memiliki amplikasi hukum yang sangat merugikan bagi istri dan anak", (Hasan Basri, Wawancara pada tanggal 1 Mei 2019).

Pasal 42 Undang-Undang Nomor 1 Tahun 1974 tentang Perkawinan dan Pasal 99 Kompilasi Hukum Islam, anak yang sah adalah anak yang dilahirkan dalam atau sebagai akibat perkawinan yang sah, jadi anak hasil nikah siri bukanlah anak yang sah. Kemudian Pasal 43 ayat (1) UndangUndang Nomor 1 Tahun 1974 tentang Perkawinan dan Pasal 100 Kompilasi Hukum Islam menyebutkan bahwa anak yang dilahirkan di luar pernikahan hanya mempunyai hubungan perdata dengan ibu dan keluarga ibunya. Sehingga anak kehilangan hak atas nama atau nasab bapaknya, adapun dampak lain yang terjadi terhadap anak yaitu nafkah lahir maupun batin, tempat tinggal, pendidikan, dan harta warisan apabila bapaknya meninggal dunia. 
Menurut Ansyaruddin anak yang tidak mempunyai hubungan hukum dengan bapaknya, akan berdampak pada piskologi jiwa anak karena dianggap anak luar nikah;

Anak haram apalagi jika ayah tidak mau bertanggung jawab dan tidak menjalankan fungsinya sebagai seorang bapak. Sementara itu, karena nikah siri tidak diakui oleh Negara, pasangan yang melakukannya tidak bisa mendapatkan surat nikah, kartu keluarga, akta kelahiran anak serta surat keterangan lainnya bagi yang bersangkutan. Karena surat-surat itu juga adalah syarat untuk membuat akta kelahiran maka sang anak pun terancam tidak diakui oleh Negara, (Ansyaruddin, Wawancara pada tanggal 26 Maret 2019).

Status anak dalam akta kelahiran dianggap sebagai anak luar nikah, sehingga hanya dicantumkan nama ibu yang melahirkannya. Seperti yang dialami oleh Kamalia Agustina, dalam pembuatan akta kelahiran anaknya hanya dicatat mengikuti ibunya karena pencatatan sipil untuk kelahiran anak mensyaratkan adanya surat nikah resmi dari Negara. Hal itu mengakibatkan hak identitasnya seseorang sebagai seorang anak tidak akan diakui bahwa dia anak dari seorang ayah yang telah melakukan nikah siri, maka nasabnya menjadi mengikuti ibunya.

Selain itu, terjadinya penelantaran anak dalam hal perkawinan tidak dicatatkan karena mengancam hak atas nasab, mewaris, pemeliharaan dan biaya kehidupan, serta pengasuhan. Menurut Ansyaruddin;

Anak yang dilahirkan dari perkawinan yang tidak dicatatkan berdampak pada pemenuhan hak-hak anak dalam hukum keluarga, dan secara bersamaan berdampak pula bagi pemenuhan hak-hak anak sebagai subyek warga Negara, seperti hak atas identitas akta kelahiran, relasi kekerabatan, kewarganegaraan. Lebih parah lagi terhadap anak yang lahir dari pernikahan siri atau yang tidak dicatatkan dengan indikasi eksploitatatif, atau yang tidak diakui nasab dan dikucilkan dari pergaulan sosial sehari-hari dengan keluarga/kerabat sehingga menghilangkan status sosial sebagai seorang anak dari ayahnya, (Ansyaruddin, Wawancara pada tanggal 26 Maret 2019).

\section{Implikasi Sosial Terhadap Kehidupan Anak dalam Lingkungan Sekolah/Pendidikan}

Nikah siri ini juga membawa implikasi negatif bagi anak yang berdampak dari segi hukum perdata ke dalam dunia pendidikan. Nikah siri juga dapat merugikan anak dikemudian hari, karena ada ketentuan yang berlaku untuk mendaftarkan sekolah si anak maka dibutuhkan persyaratan-persyaratan yang diwajibkan oleh Pemerintah untuk memiliki akte kelahiran sianak untuk bisa mengikuti pendidikan atau mau masuk 
ke sekolah, serta dunia pendidikan lainya disaat anak masih usia dini, sedangkan untuk memperoleh akta kelahiran bagi seorang anak diwajibkan mempunyai akte nikah yang resmi dari lembaga pencatatan hal ini bisa merugikan bagi anak.

Menurut Ansyaruddin, Anak yang lahir dari pernikahan yang tidak dicatatkan, dengan demikian tidak tercatatkan ke dalam sistem pencatatan kependudukan karena tidak memiliki dokumen formal yang diterbitkan Pemerintah. Hal ini menjadi hambatan yuridis sebagai pemenuhan hak atas identitas, yakni hak atas akte kelahiran. Oleh karena rezim hukum Administrasi kependudukan versi Undang-Undang Nomor 23 tahun 2006 tentang Administrasi Kependudukan, dan berbagai Qanun maupun Peraturan Bupati mengenai akte kelahiran menganut stelsel aktif bagi Penduduk. Selain itu juga mensyaratkan dokumen formal (surat nikah, Kartu Tanda Penduduk-KTP, Kartu Keluarga-KK) untuk menerbitkan akte kelahiran, membatasi jangka waktu pelaporan, dan penarikan biaya sebagai retribusi sehingga menghambat pencatatan kelahiran anak.

Jika ditelaah secara mendalam Undang-Undang Nomor 23 Tahun 2006 tentang Adinistrasi Kependudukan, maka terdapat berbagai faktor yang menghambat anak memperoleh hak identitas atas akte kelahiran, yaitu:

1) Asas "stelsel aktif bagi Penduduk".

2) Syarat-syarat formal pencatatan kelahiran (surat nikah/akte perkawinan, KK, KTP).

3) Pembatasan waktu 60 (enam puluh) hari melaporkan kelahiran menjadi hambatan dalam akses pencatatan kelahiran, jika melewatinya akan menjalani prosedur lebih panjang.

4) Pengenaan sanksi denda atas keterlambatan.

5) Tidak adanya fasilitasi dan bantuan Pemerintah.

6) Tidak adanya tindakan affirmatif untuk anak dari kawasan terisolir, anak berkesulitan khusus, anak tanda dokumen perjalanan (paspor) yang mengikuti orangtuanya bekerja di luar negeri.

7) Belum bebas biaya akte kelahiran, (Ansyaruddin, Wawancara pada tanggal 26 Maret 2019).

Oleh karena akta kelahiran adalah yang yang pertama, maka ketiadaan akte kelahiran berimplikasi luas kepada pemenuhan hak anak atas hak lain, terutama hak atas jaminan sosial dan pendidikan.

Perkembangan regulasi aturan dan kebijakan jaminan sosial yang cenderung mengarah kepada dokumen formil, maka anak yang tidak memperoleh akte kelahiran karena disebabkan oleh pernikahan yang tidak dicatat akan semakin tersingkirkan dari akses jaminan social dan jaminan lain yang besifat administrative dalam pemerintahan. Namun, Pemerintah 
semestinya tidak mengabaikan anak-anak dari pernikahan tidak dicatatkan, ataupun non marital child karena tidak absah jika diabaikan hak-haknya. Formalitas dokumen, syarat dan prosedur penyelenggaraan jaminan sosial dan pendidikan akan menghambat akses anak-anak tanpa akte kelahiran. Sehingga perlu terobosan untuk mengatasi dampak dari pernikahan tidak dicatatkan terhadap anak.

\section{Implikasi Sosial Terhadap Kehidupan Anak dalam Lingkungan Masyarakat}

Nikah siri ini juga membawa implikasi negatif bagi anak yang berdampak ke dalam lingkungan masyarakat. Lingkungan Sosial adalah segala faktor ekstern yang mempengaruhi perkembangan pribadi manusia, yang berasal dari luar diri pribadi. Masyarakat adalah golongan besar atau kecil yang terdiri dari beberapa manusia, yang dengan atau karena sendirinya bertalian secara golongan dan pengaruh mempengaruhi satu sama lain. Pengaruh dan pertalian kebatinan yang terjadi dengan sendirinya di sini menjadi unsur yang sin qua non (yang harus ada) bagi masyarakat. Masyarakat bukannya ada dengan hanya menjumlahkan adanya orang-orang saja, diantara mereka harus ada pertalian satu sama lain.

Masyarakat adalah suatu kesatuan yang selalu berubah, yang hidup karena proses masyarakat yang menyebabkan perubahan itu. Masyarakat, berarti suatu badan atau kumpulan manusia yang hidup bersama sebagai anggota masyarakat, anggota-anggota masyarakat yang bersama biasanya dianggap sebagai suatu golongan, terbagi-bagi dalam berbagai kelas menurut kedudukan dalam masyarakat itu.

Menurut Nur Afni, dampak nikah siri secara psikologi terhadap anak yaitu ketika masalah yang ditimbulkan adalah status anak di lingkungan sekitar.

Biasanya, problem bagi para anak hasil pernikahan siri itu adalah masalah pengakuan secara hukum dan sosial. Hal ini jelas berdampak secara psikologis, hingga berpotensi anak tersebut memiliki konsep yang negatif terhadap dirinya sendiri. Saat anak tersebut beranjak dewasa, maka akan banyak bertanya dan berinteraksi dengan temannya. Sejumlah ganjalan sosial terkait status anak hasil pernikahan siri ini bisa juga disebabkan karena stigma-stigma yang buruk tentang status si anak di lingkungan. Berbagai masalah mulai dari tidak diakui, penolakan status sosial, atau bahkan penghinaan sangat rentan diterima oleh anak-anak hasil pernikahan siri tersebut, (Nur Afni, Wawancara pada tanggal 18 Oktober 2019). 
Menurut Tgk. Abdul Wahab, sampai saat ini masih banyak anggota masyarakat yang melakukan perkawinan secara siri, walau sebetulnya pernikahan secara siri ini sangat merugikan pihak si isteri dan anak-anak yang dilahirkannya.

Bahkan telah berkembang wacana sebagai isu yang santer dengan munculnya "kriminalisasi nikah siri" dengan ancaman pidana bagi para pelaku dan pelaksana nikah siri, sebagai reaksi terhadap praktik nikah siri yang dianggap tidak mencerminkan keadilan dan sangat terkesan bias gender, (Tgk. Abdul Wahab, Wawancara pada tanggal 20 Maret 2019).

Menurut A. Latif Rusydi Azhari Harahap, perkawinann secara siri ini masih banyak dilakukan oleh anggota masyarakat karena pemahaman terhadap sahnya pernikahan yang rancu akibat masih adanya multi tafsir mengenai sahnya perkawinan menurut Undang-Undang Nomor 1 Tahun 1974 tentang Perkawinan;

Kemudian terkait dengan sahnya perkawinan ini dapat pula dikaitkan dengan hakekat suatu perkawinan adalah hubungan antara seorang pria dengan seorang wanita yang saling mengikatkan diri atas dasar kesepakatan (perjanjian) sebagai suami istri. Pengertian kawin atau perkawinan dapat pula dipahami sebagai menjalin kehidupan baru dengan bersuami atau beristeri, menikah, melakukan hubungan seksual, dan bersetubuh; dan disamping itu juga ada berbagai pemahaman mengenai perkawinann dari berbagai perspektif agama maupun budaya (adat) yang berbeda-beda sesuai dengan kebinekaan suku bangsa di Indonesia, (A. Latif Rusydi Azhari Harahap, Wawancara pada tanggal 26 Maret 2019).

Menurut Nazaruddin, tujuan dari diaturnya perkawinan dalam suatu undang-undang adalah tertib masyarakat dibidang hukum keluarga dan perkawinan;

Dalam arti tingkah laku anggota masyarakat untuk memenuhi kebutuhannya dalam hal perkawinan terpola dalam suatu sistem kaedah hukum lazimnya diartikan sebagai peraturan hidup yang menentukan bagaimana manusia seyogyanya berperilaku, bersikap di dalam masyarakat agar kepentingan-kepentingan orang lain terlindungi dan fungsi kaedah hukum pada hakekatnya adalah melindungi kepentingan manusia atau kelompokk manusia, kemudian tujuannya adalah ketertiban masyarakat, (Nazaruddin, Wawancara pada tanggal 26 Maret 2019).

Dengan demikian Undang-undang Nomor 1 Tahun 1974 dibuat agar masyarakat dalam memenuhi kebutuhannya dalam hal perkawinan ada 
kepastian dalam tingkah lakunya, sehingga terdapat ketertiban masyarakat dan dimaksudkan untuk memecahkan masalah-masalah masyarakat dalam lingkup hukum keluarga dan perkawinan, bukan justru menimbulkan masalahh baru dalam masyarakat.

Pada umumnya, anak-anak korban perkawinan siri biasanya terlantar dan kurang terurus baik dari segi ekonomi, kesehatan, pendidikan maupun masa depannya. Itu terjadi, karena anak nikah siri yang diasuh ibunya yang tidak mandiri secara ekonomi, karena tidak mempunyai sumber pendapatan. Hal tersebut sering terjadi pada pasangan nikah siri yang dilakukan karena alasan poligami. Suaminya sering menghabiskan waktu bersama istri sahnya sehingga istri dari nikah siri sering terabaikan dan tidak mendapatkan perhatian.

Menurut Muhammad Idris, status anak dari hasil nikah siri, si anak akan kerap menjadi perbincangan, karena statusnya yang tidak jelas orang tuanya;

Adanya sebutan anak haram atau anak luar kawin terhadap si anak tersebut adalah contoh yang sering terjadi di masyarakat, hal ini akan berlanjut dengan kesulitan si anak dalam bergaul dengan lingkungannya. Anak dari hasil perkawinan siri akan mengalami beban psikis, dengan adanya tanggapan-tanggapan negatif dari masyarakat, akan membuat anak tertekan dan kehilangan rasa percaya diri sehingga dapat mengganggu perkembangann mental si anak, (Muhammad Idris, Wawancara pada tanggal 20 Maret 2019).

\section{Implikasi Sosial Terhadap Kehidupan Anak Pasca Meninggal Orang Tua}

Nikah siri ini juga memberi implikasi negatif bagi anak yang berdampak pasca meninggalnya orang tua si anak. Pada dasarnya dalam setiap pernikahan selalu akan muncul masalah yang menyertai. Dalam pelaksanaan nikah siri dengan dalih sah secara agama, seorang laki-laki bebas untuk menikahi perempuan manapun yang dia mau, bahkan bila harus berbenturan dengan hukum positif dimana dia tinggal. Apalagi bila posisi laki-laki tersebut adalah tokoh agama yang mempunyai banyak santri, calon istri yang dinikahi merasa terangkat status sosialnya. Namun bagaimana dengan lingkungann dan masyarakat sekitar yang merasa terganggu dengan keputusan tersebut. Undang-Undang Perkawinan yang sudah diabaikan, ditambah pengabaian terhadap Undang-Undang Perlindungan Anak, perlindungann terhadap hak kesehatan reproduksi perempuan dan sebagainya.

Akibat lebih jauh dari pernikahan siri adalah anak tidak berhak menuntut warisan dari ayahnya jika meninggal dunia, karena pernikahannya tidak pernah dianggap ada menurut hukum nasional. "Dan tidak dapat menuntut pembagian harta bersama jika terjadi perceraian, 
karena tidak ada bukti authentik yang menyatakan bahwa mereka telah melaksanakann perkawinan siri”, (A. Latif Rusydi Azhari Harahap, Wawancara pada tanggal 26 Maret 2019).

Menurut Nazaruddin, ketentuan pencatatan perkawinan sebagaimana diatur dalam Pasal 2 Ayat (2) Undang-Undang Nomor 1 Tahun 1974 tentang Perkawinan bertujuan agar terjamin ketertiban perkawinan bagi masyarakat Islam (Pasal 5 Ayat (2) Kompilasi Hukum Islam) dan untuk menjamin ketertiban hukum (legal order) sebagai instrumen kepastian hukum, kemudahan hukum, di samping sebagai bukti otentik adanya perkawinan.

"Pencatatan perkawinan merupakan salah satu bentuk intervensi pemerintah atau negara untuk melindungi dan menjamin terpenuhinya hak-hak sosial setiap warga negara, khususnya pasangan suami istri, serta anak-anakk yang lahir dari perkawinan itu". Dengan demikian meskipun nikah siri tidak diakui, namun pemerintah memberikan peluang bagi pasangan nikah siri untuk mengajukan permohonan siding itsbat nikah di Mahkamah Syari'iyah untuk memperoleh kepastian hukum bagi pernikahan pasangan tersebut, (Nazaruddin, Wawancara pada tanggal 26 Maret 2019).

Terpenuhinya hak-hak sosial itu, akan melahirkan tertib sosial sehingga akan tercipta keserasian dan keselarasan hidup bermasyarakat. Berkaitan dengan itu, pencatatan perkawinan seperti yang diatur pada Pasal 2 Ayat (2) Undang-Undang Nomor 1 Tahun 1974 Tentang Perkawinan, merupakan salah satu produk politik sosial sebagai deposit politik sosial modern.

Oleh karena itu, pasangan suami istri yang telah melakukan perkawinan menurut hukum agama (Islam), tetapi tidak tercatat atau dicatatkan, cukup dilakukan pencatatan pada Pegawai Pencatat Nikah Kantor Urusan Agama dengan terlebih dahulu mengajukan permohonan itsbat nikah ke Pengadilan Agama, tanpa harus melakukan nikah ulang atau nikah baru (tajdid an-nikah) karena hal itu bertentangan dengan ketentuan Pasal 2 Ayat (1) Undang-Undang Nomor 1 Tahun 1974 tentang Perkawinann.

Berdasarkan uraian diatas dapat disimpulkan bahwa kepastian hukum terhadap pernikahan yang tidak dicatatkan tidak ada karena pernikahan yang tidak dicatatkan dianggap dilakukan tanpa memenuhi ketentuan Undang-undang yang berlaku akibatnya suami yang melalaikan kewajibannya memberi nafkah kepada anak dan istri tidak dapat dituntut ke pengadilan. Meskipun pernikahan siri telah dianggap sah secara hukum islam, namun hal tersebut telah banyak menimbulkan berbagai problematika dimana hak-hak mereka yang melakukan pernikahan siri 
tidak terlindungi hukum, karena secara legal formal mereka belum menikah.

\section{Kesimpulan}

Berdasarkan pembahasan yang berkaitan dengan permasalahan maka dapat ditarik kesimpulan sebagai berikut: pertama, praktik nikah siri di Kabupaten Aceh Tamiang sudah berlangsung sejak lama di Desa Lhok Medang Ara dan Desa Sampaimah Kecamatan Manyak Payed dan dianggap hal yang biasa oleh masyarakat meskipun dilakukan secara terselubung dan sulit dideteksi. Pelaku nikah siri kebanyakan sudah pernah menikah sebelumnya dan kesulitan mendapatkan akta cerai atau izin dari Mahkamah Syar'iyah, dan dianggap solusi untuk menghindari perbuatan zina, serta kondisi sosial budaya masyarakat yang menganggap nikah siri merupakan unsur privat dalam beragama dan sah secara agama.

Kedua, implikasi sosial nikah siri terhadap kehidupan anak di Aceh Tamiang yaitu menimbulkan implikasi sosial terhadap kehidupan anak dalam lingkungan keluarga seperti hilangnya hubungan perdata dengan ayahnya, implikasi sosial terhadap kehidupan anak dalam lingkungan sekolah/pendidikan tidak dapat membuat akta kelahiran yang menjadi hal penting dalam pengurusan administrasi dunia pendidikan, implikasi sosial terhadap kehidupan anak dalam lingkungan masyarakat yaitu dianggap rendah sebagai anak haram dan sering menjadi alat ekploitasi, serta implikasi sosial terhadap kehidupan anak pasca meninggal orang tua yaitu anak tidak dapat menuntut hak warisan dari ayahnya. 
Samsul Bahri

\section{Daftar Pustaka}

Anderson, I.N.D. 1994. Hukum Islam di Dunia Modern. Yogyakarta: Tiara Wacana.

al-Shabbaqh, Mahmud. 2004. Tuntunan Keluarga Bahagia Menurut Islam. Ahli Bahasa Bahruddin Fannami, Cet ke 3, Mesir: Dar al-I'tisham

az-Zuhaili, Wahbah. 2011. Fiqih Islam wa Adillatuhu. alih bahasa Abdul Hayyie al-Kattani, cet. Ke-1. Jakarta: Gema Insani.

Mukhtar, Kamal. 2009. Asas-Asas Hukum Islam Tentang Perkawinan. Cet.3, Jakarta: Bulan Bintang.

Mughniyah, Muhammad Jawad. 2008. Fikih Lima Mazhab. Cet. Ke-8, Terjemahannya. Jakarta: Lentera.

Nasution, Khairuddin. 2005. Hukum Perkawinan. Yogyakarta: Tazzafa.

Thalib, Sayuti. 2009. Hukum kekeluargaan Indonesia. Jakarta: Penerbit UI Press.

Yunus, Mahmud. 1996. Hukum Perkawinan Dalam Islam Menurut Mazhab Syafi'I, Hanafi, Maliki dan Hanbali. Jakarta: Hidakarya Agung. 